\title{
FAKE NEWS AND INFORMATION PROFESSIONALS' CODES OF ETHICS
}

\author{
Juan-José Boté-Vericad* \\ https://orcid.org/0000-0001-9815-6190
}

RECIBIDO: Mayo 2020 / ACEPTADO: Julio 2020 / PUBLICADO: Septiembre 2020

Como citar: Boté-Vericad, Juan-José (2020). Fake News and Information Professionals' Codes of Ethics. Telos: revista de Estudios Interdisciplinarios en Ciencias Sociales, 22 (3), Venezuela. (Pp.567-578).

DOI: www.doi.org/10.36390/telos223.07

\section{ABSTRACT}

The goal of this paper is to discuss concepts related to Fake News. The study includes the different meanings of Fake News, along with related information disorders. It also includes an analysis of information professionals' ethical codes in relation to information disorders and ethical behaviours regarding information management. The speed and ease with which Fake News can be disseminated has implications for these information professionals. The literature review explore some of the different taxonomies and typologies of Fake News published by the following authors: Aznar (2019), Froehlich (2017), Verstraete, Bambauer and Bambauer (2017) and Wardle and Derakshan (2017). Methodologically, this paper analyzes the information professionals' codes of conduct for the main organizations and associations, in a thoughtful manner. These codes of conduct include those published by the International Federation of Libraries (IFLA, 2017), the American Library Association (ALA, 2017), the Association for Information Sciences and Technology (ASIS\&T, 1992), and the Society of Professional Journalists (Society of Professional Journalists, 2014). We also discuss guidelines to avoid unethical behaviours relating to information. The conclusions inferred from this study are that Fake News impacts many different disciplines, such as economics and science. However, information professionals, through their codes of conduct and aided by technology, can help society prevent the spread of Fake News.

Keywords: Fake News, information professionals, disinformation, ethical codes, codes of conduct.

\footnotetext{
* Departament de Biblioteconomia, Documentació i Comunicació Audiovisual \& Centre de Recerca en Informació, Comunicació i Cultura. Universitat de Barcelona. C/ Melcior de Palau 140, 08014 ES, Barcelona. Correo electrónico: juanjo.botev@ub.edu
} 


\section{Fake News y los códigos éticos de los profesionales de la información}

\section{RESUMEN}

El objetivo de este artículo es debatir los conceptos relacionados con las Fake News. Estos conceptos están relacionados con los diferentes significados de las noticias falsas, el trastorno informativo, así como analizar códigos éticos de los profesionales de la información frente a los desórdenes informativos y al comportamiento ético con respecto a la gestión de la información. La rapidez y facilidad con las que se pueden difundir las noticias falsas tiene implicaciones en estos profesionales. En la revisión de la literatura se exploran las diferentes taxonomías y tipologías de Fake News publicadas por los siguientes autores: Aznar (2019), Froehlich (2017), Verstraete, Bambauer y Bambauer (2017) y Wardle y Derakshan (2017). Así, se debate de forma reflexiva los códigos de conducta de las principales organizaciones y asociaciones de estos colectivos. Metodológicamente se analiza de manera reflexiva la información de los códigos profesionales de conducta de los profesionales de la información para las principales organizaciones y asociaciones. Se analizan los códigos publicados por la Federación Internacional de Bibliotecas (IFLA, 2017) y otras entidades también relevantes como la Asociación Americana de Bibliotecas (ALA, 2017), la Asociación de Ciencias de la Información y Tecnología (ASIS\&T, 1992) y Sociedad de periodistas profesionales (Society of Professionals Journalists, 2014). Se muestra también unas pautas para evitar comportamientos no éticos con la información. Las conclusiones que se derivan de este estudio es que las Fake News impactan en muy diversos ámbitos como la economía o la ciencia. No obstante, los profesionales de la información mediante sus códigos de conducta pueden ayudar a la sociedad a evitar la diseminación de noticias falsas, pero también ayudados por la tecnología.

Palabras clave: Fake News, profesionales de la información, desinformación, códigos éticos, códigos de conducta.

\section{Introduction}

The dissemination of fake news generally involves one or more different goals for spreading them. The first goal encompasses using news to damage someone's reputation with false, biased, or misleading information. Another is earning money through advertising based on click-bait techniques (Alvarez, 2017). These two examples show that fake news may have different uses and faces.

The internet and social media in particular, allow the end user to easily and quickly disseminate any type of information in several different forms. Additionally, many institutions and information professionals such as members of the media, journalists, political parties, politicians, or financial companies are constantly facing fake news. As literature shows, social media is heavily utilized to spread fake news. For example, a study in the United States showed that $55 \%$ of the population believed that false social media profiles are responsible for the spread of Fake News (Richter, 2019).

Fake news tends to alter the reality of a story, and consequently it is difficult to change a receiver's mind once it has been altered. False news can provide a feeling of familiarity and 
truthfulness based on the illusory truth paradigm (Jackson, 2019). This sense of truthfulness enables the consumption of this sort of content.

There are several motivations for the creation and consumption of fake news. Some of the root causes of fake news include online communication, economic aspects (Blanco-Herrero \& Arcila - Calderón, 2019), the lack of a centralized control mechanism for news consumption on social media platforms, and a decreasing trust of media (Budak, 2019). For instance, in Finland $59 \%$ of the population surveyed places trust in media, but in the United States only $32 \%$ seem to trust the news media, which is close to the levels of Slovakia (33\%) or Malaysia (31\%) (Watson, 2019).

Bearing that in mind, it seems that the smaller budgets for traditional media to verify information and produce more rigorous work, together with a lack of online content control has enabled the spread of fake news.

In economic terms, fake news has a low cost of production and a high rate of dissemination because of how cheaply the content can be shared with millions of people (Khodabakhsh, Busch \& Ramachandra, 2018; Landon-Murray, Mujkic \& Nussbaum, 2019). Technology will continue to reduce the cost of creating and spreading fake news, and rapid advances in artificial intelligence (hereafter Al) will bring different and likely even faster approaches, effects, and form of content delivery. One example of this approach are the deepfakes, consisting of a modified video using Al.

The aim of this paper is to provide an overview of information disorder and unethical information, as well as a discussion of the codes of conduct of information professionals and suggested guidelines for avoiding unethical information behaviour in relation to information disorder.

\section{Information disorder, typologies and taxonomies of the fake news}

Prior to discussing the different taxonomies proposed in literature, it is necessary to discuss the meaning of information disorder and the role of fake news in it. Information disorder is the process of spreading false information with generally harmful consequences to the receiver who interprets the information. Fake news it is not a new invention. It has been used many times in politics and wars, but currently presents a challenge to citizens as misinformation is produced in a larger scale (Aznar, 2019).

Depending on the harm caused by the content, information disorder can encompass disinformation, misinformation and malinformation. Therefore, fake news is a form of information disorder, along with hoaxes, clickbait, bogus stories, and conspiracy theories. Thus, misinforming does not have the intention to harm (Sellnow, Parris \& Semenas, 2019; Wardle \& Derakhshan, 2017), while disinformation and malinformation have harmful intents.

Hoaxes, trolling, and propaganda are false or biased news that tend to deceive the reader. Contrarily, satire and humour, which create another genre of fake news, do not tend to misguide the reader (Verstraete, Bambauer \& Bambauer, 2017). In addition, information disorder could encompass other words not necessarily relating to the information itself, but rather, as fake followers, sock puppets, trolling or other more technological information such as artificial intelligence, algorithms, or bots because these tools are used to spread fake news (Wardle, 2018).

Some authors suggest that is difficult to make concrete taxonomies for fake news, but 
there have been some attempts, such as a taxonomy for varieties of ignorance: ignorance per se, disinformation, misinformation, missing information, self-deception or bad faith and dominant forms of calumny, doxing and fake news (Froehlich, 2017). Another study suggested another taxonomy based on characterizing the source where fake news is disclosed, anonymous and bogus (Berghel, 2017).

Finally, another type of fake news, deepfakes, which is multimedia content, could have its own taxonomy of the different impersonation technologies and be divided into physical and digital forms (Khodabakhsh, Busch \& Ramachandra, 2018). On deepfakes, a high level of technology plays a huge role in modifying informational content because it requires the use of $\mathrm{Al}$ and machine learning algorithms are essential in the creation of false videos since movement, voices, and body gestures or faces need to be changed.

\section{Unethical information behaviour in different fields}

Information use can be viewed according to what is considered unethical behaviour. For instance, when comparing the use of information in two popular cases, Wikileaks or the Donald Trump 2016 election, there is likely to be agreement that both cases involve unethical behaviour: even though these are two completely different cases involving information management, as they both involve politics. Unethical information behaviour not only exists in news, but also in politics, science, economics and in the financial industry.

In the case of political economy, a study used game-theory political economy models and concluded that citizens might lose welfare when making economic choices based on misleading information. Hiding information from citizens seems to lead to reduced access to welfare. Therefore, the risk of decreasing welfare also exists when there is a need to detect misleading information to prevent political decisions (Bullock, Mittenzwei \& Josling, 2019). Particularly misleading information in politics could result in election fraud (Peña, 2017) and lower citizen participation levels in democratic processes (Manzanero \& Ramírez, 2018).

There are several known cases around the world in relation to scientific fields where information is misleading or biased, causing problems later to not only the creator's credibility, but also to the publishers. For instance, in recent years in Spain, more than 1280 researchers were retracted by misconduct relating to their research (Abril - Ruiz, 2019). It is also possible to find a more accurate number of authors in the retraction databases from other countries'.

There are also well-known cases relating to individual authors or research groups. For instance, in the field of diabetes research, after a principal investigator died, her colleagues published a paper of her research, but data were manipulated (Schneider, 2018a). A genetics researcher was found to have published several papers manipulating data (Schneider, 2018b). There is pressure on researchers to publish scientific papers in order to obtain funding. Consequently, researchers might risk their professional careers by manipulating research data, which is a misinformation problem, even with a peer-reviewed process as is used in academia. Thus, the peer-review system in academia seems to be a good gatekeeper but it is likely not enough and should be improved.

Manipulating data in experiments or labs may have a risk that research cannot be repeated in similar conditions. Another question is the credibility of the scientist or the group of scientists who have published the data. However, this does not always lead to the spread of

${ }^{1}$ Available from http://retractiondatabase.org/ access: 2020/05/10 
confusion. In the case of health emergencies, two social networking sites (hereafter SNS), Twitter and Sina Weibo, were analysed and it was found that misinformation about Ebola was at a very low level (Fung et al., 2016).

In banking, financial misinformation was and is likely to be common in most countries. For instance, a study in Chile showed that users placed more trust in banking misinformation practices, even when social movement organizations provided counterinformation against these practices (Guzmán, 2015). In another study it was found that when disseminating misleading information through media, it was not possible to show a price discovery process in capital markets (Kyung \& Marquardt, 2018).

In some cases, it is possible to verify information through fact-checking tools, repeating experiments in the case of science or learning financial mathematics to avoid being misinformed by banking practices (Neri, Ramos y Caro, 2020). It still is more difficult when false information appears in media where it is harder to verify, such as TV programmes where information or misinformation is shown live. Consequently, audiences can be misinformed with an exceptionally low ability to double check this information.

\section{Codes of conduct of information professionals}

In this section the codes of conduct of information professionals are discussed. These codes of conduct are used daily in their work, allowing them to spot fake news.

Librarians and archivist professionals' associations have their own guidelines regarding ethics relating to information. For instance, the International Federation of Libraries Association (hereafter IFLA) outlines the importance of neutrality in access to information guidelines: "Access to information: Librarians and other information workers reject the denial and restriction of access to information and ideas most particularly through censorship whether by states, governments, or religious or civil society institutions" (IFLA, 2016).

This statement relates not only to censorship, but also to freedom of information or intellectual freedom and neutrality. The American Librarian Association (hereafter ALA) expresses similar ideas in their ethics code for library professionals (ALA, 2017). In addition, the Association for Information Science and Technology (hereafter ASIS\&T) professional guidelines state that "To resist all forms of censorship, inappropriate selection and acquisitions policies, and biases in information selection, provision and dissemination" (ASIS\&T, 1992). The increase of censorship leads to decreased access to information, but under some circumstances some subsets of citizens may learn to evade censorship, especially government censorship to access information (Hobbs \& Roberts, 2018). In the long term, it is likely that some fake news will be archived, for research purposes.

According to the guidelines above, information professionals would provide any requested information to their users, even when this information is false, along with advice about the origin of the information. As such related to neutrality: "Librarians and other information workers are strictly committed to neutrality and an unbiased stance regarding collection, access and service" (IFLA, 2016).

In the fake news context, information professionals have the difficult task of offering information that may be biased, misleading or perhaps ignored. These professionals cannot always be neutral since they shape information for users and some sources of information, such as those from minorities, political dissenters, or ethnic groups could be involuntarily avoided 
(Gibson et al., 2017).

In addition, since fake news may affect net neutrality, users' behaviour may change and the dismantling of the net neutrality makes it challenging to ensure that there is equal access to resources for citizens at risk, as well as for information professionals (Adams \& Harris, 2018). Internet service providers may not only decide to slow down traffic from certain sources but may also permit content that aligns with certain political views. This would be controversial for information professionals, as they avoid providing erroneous or misleading information and promote equal access to information (ASIS\&T, 1992).

Journalists, another information professional who delivers content, also have a code of conduct. The code of ethics of the Society for Professional Journalists highlights the fact that journalists' work must be accurate, verifying and correcting information when necessary (Society of Professionals Journalists, 2014). In the case of journalism, these statements are in contrast with the fact that $44 \%$ of the worldwide population surveyed had detected fake news in print media. In the case of Turkey, $72 \%$ of printed media, and in the United States $47 \%$ of printed media news are considered fake news (Watson, 2019). In addition, 28\% of the population of the United States who were surveyed said that they believe that CNN are spreading disinformation and $30 \%$ believe Fox News is doing the same (Richter, 2019).

\section{Guidelines to Avoid Unethical Information Behaviour}

As mentioned, users are constantly exposed to these three types of information disorders. Information in the form of text, images, audio or video may contain biased information. In fact, Fake News affects all countries across all scenarios such as the economy, health, politics, employment and business, among others. To survive in the face of this unethical information behaviour, users and information professionals have technological and educational solutions.

In terms of technological solutions, there are different useful strategies especially when this information come from a source, anonymous or not. One of these strategies, and likely the most used, is the use of fact-checking or reverse image search tools to detect this sort of false information. The main issue is that this strategy is done "in the past tense" when the harm is likely already done.

Moreover, in extreme cases where emotions play an important role, such as religion, politics or activism, this is likely not possible. For instance, in the days leading up to the Catalan Referendum in October 2017, thousands of messages were spread on WhatsApp groups and online forums. Some of these messages were credited to famous people or reputed professionals who were in favour of or against the independence process. However, some of them were completely false (Rubio, 2017). It is difficult for users to verify this information if the person or organization involved has not really denied or approved, in most cases publicly, this information. In countries like India, the government shuts down not only the websites which spread misinformation online, but it also blocks internet access to citizens, as in the case of Kashmir in 2017. However, this is a costly solution because of a negative influence on the economy caused by the blocking of access, leading to loss of money and business competitiveness (Kaur et al., 2018).

Other solutions proposed include the use of an Al process to detect and spot false information (Granik \& Mesyura, 2017). However, this sort of solution is not generalised to all SNS, is experimental, and needs to be studied and developed in more depth.

In regard to educational solutions, most authors are in favour of improving the 
information literacy skills of users. This enables users to be critical about the type of content they are viewing, along with its source, the evidence, interpretation, completeness and knowledge (Houtman \& Wall, 2019; Rosenstiel, 2013). A study proposed a theorical framework based on three phases: pre-contribution, during contribution, and post-contribution, particularly addressed to the gallery, library, archive and museum (hereafter GLAM) sectors (Qutab, Myers \& Gardner, 2019). Therefore, this sort of solution is most useful when the information is within the realm of information professionals, ideally in a closed environment.

Information literacy reinforcement programmes have been adapted to current times, also emphasizing the importance of the information selection process (Lopez-Borrull, VidesGràcia \& Badell, 2018). In this way, users are trained by information professionals to distinguish false information. Otherwise, misleading or false information can be disseminated and, even worse, the user manipulated. For instance, at Stanford University, information literacy is a classroom priority using discipline-specific examples, reviewing fake news and propaganda and demonstrating that it affects all subject areas (Benson, 2019)

To users, before sharing information it is important to verify it. Ideally, this process should be automatic and preferably transparent. This is also a credibility and reputational issue. Users who share checked and verified information are more likely to be reliable. However, Asian countries such as Japan, Singapore, or South Korea do not have easy methods to verify information as there is not an established media practice or there are not enough solutions (Kaur et al., 2018).

The issue for the user arises when this information is from an official channel that is supposed to be trustworthy, such as a newspaper or a TV channel. Thus, the solution currently seems difficult to determine whether it be by technical or manual means.

Without a unique solution to avoid unethical information behaviour, information professionals have to reinforce information and media literacy among users so that they can readily spot misinformation, but media also have an obligation to work ethically.

\section{Discussion}

The spread of fake news has social implications and its influence on the economy, politics, culture or welfare is bigger than we may think. There are no easy solutions for spotting fake News and inoculating against it as we do for viruses (Cook, Lewandowsky \& Ecker, 2017). Solutions could work in certain fields or situations, but not in all them.

Information disorder is not an involuntary act. There is intent and planning behind the spread of false news. And the term intent refers to a well-thought out strategy to change user perception which can be a calm reaction, such as to change someone's opinion about a topic, but it can also be violent, such as in the area of religion, which can be extreme. Therefore, different types of fake news can be used in the publishing context, not just the spread of false information, but other types including hoaxes, trolling, or propaganda, used individually or as part of a mixed strategy. In relation to that, I think that information literacy is not the complete solution to detect the dissemination of false news, but the use of technology is essential to mitigate the harms and other side effects of fake news (Leetaru, 2019).

Once false news is spread, the harm is done, and it is exceedingly difficult to use countermeasures with a similar impact. The financial investment required to spot the harm of false news has not been quantified, but it is certain that it would not be the same amount of 
money as the creation, production and spread of false information, but I believe it would certainly be more. In Reuters Digital Report 2018 (Reuters Institute for the Study of Journalism, 2018) it was suggested that government interventions are expected in European and Asian countries, but I think that legislative measures would not have a real dissuasive effect, even with economic punishment. Thus, some governments and lobbyists worldwide use false news for their own benefit. One example is the case of Brexit (Tattersall, 2018). This is one of the contradictions of the initiative to spot the Fake News effect through legislative initiatives.

The information professionals' code of conduct enables them to be a reliable source in offering training about information literacy to users, and when curating content to provide reliable information to users. However, information professionals may also need the support of other professionals such as scientists or lawyers to evaluate information misconduct.

Finally, another question to consider is training in information literacy. Information literacy offers what ethics cannot offer such as sources' selection and evaluation. Therefore, training in media or information literacy not only needs content curation strategies but an ethics strategy. In addition, false news can be part of the worldwide indicators of education. Measuring the information literacy of a country would likely also involve measuring their level of education. It is likely that the PISA test could measure information literacy level as an indicator. PISA indicators measure levels of reading and understanding, among other performance indicators (Organisation for Economic Cooperation and Development, 2016), and information literacy. Given that fake news is a global problem, it is possible that creating indicators with the PISA test could help to understand this urgency and minimize risks.

\section{Conclusions}

The rise of fake news has led to new research areas for information professionals, including ethics, trustworthiness, information selection and content curation. Moreover, as technology continues to evolve, it is likely that new varieties of fake news will appear.

As mentioned previously, fake news has a low barrier to entry in terms of cost and ease of production, so it is quite easy to spread. Anyone with harmful intent, whether physical or psychological, has the power to modify users' behaviour. This can have an impact on economics, science and business, among others. In addition, the neutrality of the internet is also affected since users generally do not have other information sources, especially in areas where internet connections may be limited.

It seems logical that information professionals' codes of conduct do not fully prevent the spread of fake news. However, librarians, archivists, documentalists and other educational professionals have a unique opportunity to engage users to reinforce information literacy. Helping users to avoid fake news is not an easy matter, but with the right tools at their disposal, they would be better informed and able to use good judgement. Future research areas could include the influence of fake news in education and information literacy programmes.

\section{References}

Abril-Ruiz, Angel. (2019). El IP d mi dpto (@sruizdemaya) decía q una publicación no tenía valor si no aportaba nuevo conocimiento. Aquí va algo nuevo:) > la lista de investigadores españoles por $n^{\circ}$ de artículos retractados-Más de 1280 han sido «pillados» y creciendo \#ResearchMisconduct \#ManzanasPodridas. Extracted from https://twitter.com/aabrilru/status/1107262500112945156 
Adams, Helen \& Harris, Christopher. (2018). Net Neutrality: Why It Matters to School Librarians. Extracted from https://www.thefreelibrary.com/Net+Neutrality\%3A+Why+lt+Matters+to+School+L ibrarians.-a0537982243

Alvarez, Barbara. (2017). Public Libraries in the Age of Fake News. Extracted from http://publiclibrariesonline.org/2017/01/feature-public-libraries-in-the-age-of-fakenews/

American Library Association. (2017). Professional Ethics. Tools, Publications \& Resources. Extracted from http://www.ala.org/tools/ethics

Association for Information Science and Technology. (1992). ASIS\&T Professional Guidelines. Extracted from https://www.asist.org/about/asist-professional-guidelines/

Aznar, Hugo. (2019). Information Disorder and Self-Regulation in Europe: A Broader NonEconomistic Conception of Self-Regulation. Social Sciences. Volume 8, No. 10. Switzerland. (Pp. 280-295). DOI: https://doi.org/10.3390/socsci8100280

Benson, Megan. (2019). Teaching information literacy: Combating fake news through libraryfaculty collaboration. Journal of New Librarianship. Volume 4, No. 2. United Stated. (Pp. 538-541). DOI: https://doi.org/10.21173/newlibs/8/8

Berghel, Hal. (2017). Lies, Damn Lies, and Fake News. Computer. Volume 50, No. 2. United States. (Pp. 80-85). DOI: https://doi.org/10.1109/MC.2017.56

Blanco-Herrero, David, \& Arcila-Calderón, Carlos. (2019). Deontología y noticias falsas: Estudio de las percepciones de periodistas españoles. El Profesional de la Información. Volume 28, No. 3. Spain. DOI: https://doi.org/10.3145/epi.2019.may.08

Budak, Ceren. (2019). What Happened? The Spread of Fake News Publisher Content During the 2016 U.S. Presidential Election. The World Wide Web Conference. San Francisco. United States. DOI: https://doi.org/10.1145/3308558.3313721

Bullock, David; Mittenzwei, Klaus \& Josling, Timothy. (2019). Social Welfare Effects of Transparency and Misinformation in a Political Economy. Journal of Agricultural and Applied Economics. Volume 51, No. 3. United States. (Pp. 485-494). DOI: https://doi.org/10.1017/aae.2019.17

Cook, John; Lewandowsky, Stephan \& Ecker, Ullrich. (2017). Neutralizing misinformation through inoculation: Exposing misleading argumentation techniques reduces their influence. PLOS ONE. Volume 12, No. 5. United Kingdom. DOI: https://doi.org/10.1371/journal.pone.0175799

Froehlich, Thomas. (2017). A Not-So-Brief Account of Current Information Ethics: The Ethics of Ignorance, Missing Information, Misinformation, Disinformation and Other Forms of Deception or Incompetence. BiD: Textos Universitaris de Biblioteconomia i Documentació. Volume 39. Spain. DOI: https://dx.doi.org/10.1344/BiD2017.39.8

Fung, Isaac; Fu, King-Wa; Chan; Chun-Hong, Chan, Shing, Benedict, Chi-Ngai, Cheung; Abraham, Thomas \& Tse, Zion. (2016). Social Media's Initial Reaction to Information and Misinformation on Ebola, August 2014: Facts and Rumors. Public Health Reports. Volume 131, No. 3. United States. (Pp. 461-473). DOI: https://doi.org/10.1177/003335491613100312

Gibson, Amelia; Chancellor, Renate; Cooke, Nicolle; Park, Sarah; Lee, Shari and. \& Shorish, Yasmeen. (2017). Libraries on the frontlines: Neutrality and social justice. 
Equality, Diversity and Inclusion, Volume 36, No. 8, United Kingdom. (Pp. 751766). DOI: https://doi.org/10.1108/EDI-11-2016-0100

Granik, Mykhailo \& Mesyura, Volodymyr. (2017). Fake news detection using naive Bayes classifier. 2017 IEEE First Ukraine Conference on Electrical and Computer Engineering (UKRCON). Kyiv. Ukraine. DOl: https://doi.org/10.1109/UKRCON.2017.8100379

Guzmán, Sebastián. (2015). "Should I Trust the Bank or the Social Movement?" Motivated Reasoning and Debtors' Work to Accept Misinformation. Sociological Forum. Volume 30, No. 4. United States (Pp. 900-924). DOI: https://doi.org/10.1111/socf.12201

Hobbs, William \& Roberts, Margaret. (2018). How Sudden Censorship Can Increase Access to Information. American Political Science Review. Volume 112, No. 3. United States (Pp. 621-636). DOI: https://doi.org/10.1017/S0003055418000084

Houtman, Eveline \& Wall, Margaret. (2019). Information disorder: Helping students to think critically about the news. TRY+ Library Staff Conference. Toronto. Canada. Extracted from http://hdl.handle.net/1807/94747

International Federation of Library Associations. (2016). IFLA Code of Ethics for Librarians and other Information Workers (full version). Extracted from https://www.ifla.org/publications/node/11092

Jackson, Daniel. (2019). Ethics in fake news: Combatting the illusory truth effect with corrections. Master Thesis. Towson University. United States. Extracted from http://hdl.handle.net/11603/12914

Kaur, Kanchan; Nair, Shyam; Kwok, Yenni; Kajimoto, Masato; Chua, Yvonne; Labiste, Diosa; Soon, Carol; Jo, Hailey; Lin, Lihyun; Le, Trieu \& Kruger, Anne. (2018). Information Disorder in Asia and the Pacific: Overview of Misinformation Ecosystem in Australia, India, Indonesia, Japan, the Philippines, Singapore, South Korea, Taiwan, and Vietnam. Research report. The university of Hong-Kong. Hong-Kong. DOI: http://dx.doi.org/10.2139/ssrn.3134581

Khodabakhsh, Ali; Busch, Christoph \& Ramachandra, Raghavendra. (2018). A Taxonomy of Audiovisual Fake Multimedia Content Creation Technology. 2018 IEEE Conference on Multimedia Information Processing and Retrieval (MIPR). Miami. United States. DOI: https://doi.org/10.1109/MIPR.2018.00082

Kyung, Hangsoo \& Marquardt, Carol. (2018). Disseminating Misinformation through

Business Press. Research report. University of Hawai'i at Manoa. United States.

Extracted from http://hdl.handle.net/10125/59319

Landon-Murray, Michael; Mujkic, Edin \& Nussbaum, Brian. (2019). Disinformation in Contemporary U.S. Foreign Policy: Impacts and Ethics in an Era of Fake News, Social Media, and Artificial Intelligence. Public Integrity. Volume 21, No. 5. England (Pp. 512-522). DOI: https://doi.org/10.1080/10999922.2019.1613832

Leetaru, Kalev. (2019). A Reminder That 'Fake News' Is An Information Literacy Problem-Not A Technology Problem. Forbes. Extracted from https://www.forbes.com/sites/kalevleetaru/2019/07/07/a-reminder-that-fake-newsis-an-information-literacy-problem-not-a-technology-problem/

Lopez-Borrull, Alexandre; Vives-Gràcia, Josep \& Badell, Joan-Isidre. (2018). Fake news, ¿amenaza u oportunidad para los profesionales de la información y la 
documentación? El Profesional de la Información. Volume 27, No. 6. Spain (Pp. 1346-1356). DOI: https://doi.org/10.3145/epi.2018.nov.17

Manzanero, Nelson \& Ramírez, Miguel (2018). Diálogos sobre educación democrática: Mirada intercultural de la formación de ciudadanos latinoamericanos. Telos Revista de Estudios Interdisciplinarios en Ciencias Sociales. Volume 20, No. 1. Venezuela. (Pp. 101-128). DOI: https://doi.org/10.36390/telos201.06

Neri, Abrahan, Ramos, Santiago; \& Caro, Felix. (2020). Herramientas google en el aprendizaje de matemática financiera en los estudiantes universitarios. Telos Revista de Estudios Interdisciplinarios en Ciencias Sociales. Volume 22, No. 2. Venezuela (Pp. 429-444). DOI: https://doi.org/10.36390/telos222.13

Organisation for Economic Cooperation and Development (OECD). (2016). PISA 2015 Results (Volume I): Excellence and Equity in Education, PISA, OECD Publishing, Paris.

DOI: http://dx.doi.org/10.1787/9789264266490-en

Peña, Marysergia. (2017). Vista de Democracia representativa y participación ciudadana en Venezuela (1958-2015). Telos Revista de Estudios Interdisciplinarios En

Ciencias Sociales. Volume 19, No. 1. Venezuela (Pp. 3-26).

Qutab, Saima; Myers, Michael \& Gardner, Lesley. (2019). Information disorder in the glam sector: The challenges of crowd sourced contributions. ECIS 2019 Proceedings. 27th European Conference on Information Systems (ECIS). Stockholm \& Uppsala, Sweden. Extracted from https://aisel.aisnet.org/ecis2019 rip/37/

Reuters Institute for the Study of Journalism. (2018). Digital News Report 2018. Extracted from

https://agency.reuters.com/content/dam/openweb/documents/pdf/news-

agency/report/dnr-18.pdf/

Richter, Felix. (2019). Infographic: Who's Responsible for Spreading Disinformation? Statista Infographics. Extracted from https://www.statista.com/chart/18540/responsibilityfor-spreading-disinformation/

Rosenstiel, Tom. (2013). Six questions that will tell you what media to trust. Extracted from https://www.americanpressinstitute.org/publications/six-critical-questions-can-useevaluate-media-content/

Rubio, Jaime. (2017). Isabel Coixet no ha escrito la carta 'a todos mis amigos internacionales' sobre Cataluña. Extracted from https://verne.elpais.com/verne/2017/10/03/articulo/1507040548 973881.html

Schneider, Leonid. (2018a). Zombie scientist Sonia Melo awarded by AstraZeneca. Extracted from https://forbetterscience.com/2018/05/03/zombie-scientist-sonia-meloawarded-by-astrazenecal

Schneider, Leonid. (2018b). Another dead scientist framed with manipulated data?. Extracted from https://forbetterscience.com/2018/07/04/another-dead-scientist-framed-withmanipulated-datal

Sellnow, Timothy; Parrish, Adam \& Semenas, Lauren. (2019). From Hoax as Crisis to Crisis as Hoax: Fake News and Information Disorder as Disruptions to the Discourse of Renewal. Journal of International Crisis and Risk Communication Research. Volume 2, No. 1. United States (Pp. 121-142). DOI: https://dx.doi.org/10.30658/jicrcr.2.1.6 
Society of Professionals Journalists. (2014). SPJ Code of Ethics. Extracted from https://www.spi.org/ethicscode.asp

Tattersall, Andy. (2018). In the era of Brexit and fake news, scientists need to embrace social media. LSE Brexit. Extracted from http://blogs.Ise.ac.uk/brexit/2018/08/31/in-theera-of-brexit-and-fake-news-scientists-need-to-embrace-social-medial

Verstraete, Mark; Bambauer, Derek \& Bambauer, Jane. (2017). Identifying and Countering Fake News. Arizona Legal Studies Discussion Paper. DOI: http://dx.doi.org/10.2139/ssrn.3007971.

Wardle, Claire \& Derakhshan, Hossein. (2017). Information disorder: Toward an interdisciplinary framework for research and policy making. Research report. Council of Europe. Extracted from https://edoc.coe.int/en/media/7495-information-disorder-towardan-interdisciplinary-framework-for-research-and-policy-making.html/

Wardle, Claire. (2018). Information Disorder: The Essential Glossary. Extracted from https://firstdraftnews.org/wp-content/uploads/2018/07/infoDisorder_glossary.pdf/

Watson, Amy. (2019). Trust in news media worldwide 2019. Extracted from https://www.statista.com/statistics/308468/importance-brand-journalist-creatingtrust-news/ 